\title{
Political Violence and Socio-Economic Development in Nigeria
}

\author{
Denen, Grace Mbaveren \\ Department of Sociology \\ Plateau State University, \\ Bokkos-Nigeria
}

\section{Doi:10.5901/mjss.2013.v4n7p41}

\section{Abstract}

This paper has established impacts of violence on socio-economic development in Nigeria, and recommended the way forward.

\section{Introduction}

Violence has occurred so often in Nigeria, and elsewhere, that it is considered 'normal', except when there is a major loss of lives and property-as those instances in Syria, Egypt, Israel-Pakistan, America (Sept $11^{\text {th }}$ 2001), DR, or Congo, Nigeria (Niger delta, Borno, Yobe Plateau, Bauchi). "Charred remains of buildings, commercial centres, as well as hulks of cars, trucks serve as mute testimonies of violence" (Adrian, 2011, Alubo, 2011). The main objective of this paper is to examine the likely causes of political violence, and their negative effects on the socio-economic development of the people in Nigeria.

\section{Political Violence}

Political violence is the use of destructive means or methods in an unlawful manner against persons, property, institutions, in order to publicise grievances, coerce or intimidate a government, opponents, the civilian population, in furtherance of political, socio-economic, religious objectives. It is terror and destruction that is systematically, planned and executed, to achieve political goals. The targets often include; Government functionaries and institutions, identified individuals or groups, innocent public-bystanders, traders, and so on (http://legal-dictionary-thefreedictionary.com/political-violence).

Howell (2004) sees political violence as synonymous with 'thuggery' activities and means 'brutal' acts or behaviour by ruffians. To him, politics is the tireless repetition of misleading facts designed to depict an opponent as personally despicable, and in regard to governance, as dangerous to physical and spiritual life of a persons or nation. Violence involves acts characterized by rudeness, hooliganism, touting, intimidation and harassment. It involves behaviour that contradicts peace, harmony, interdependence among groups of people.

Political violence is an illegitimate and destructive means of seeking political power with a view to subverting popular opinion for parochial ends through self imposition. Therefore, political violence is simply the "criminalization of politics, to scare off the 'good' people, leaving politics in the hands of ruffians, thugs, hooligans, touts", etc. Violence in politics is the entrenchment of the hijack syndrome, of the right of the people to participate in the decision making process of matters that concern their welfare and development. Karl Schmit (In Schaefer, 2011) is of the view that, political violence, and violence generally is a disturbance to political equilibrium. Gur, (in NEPAD, 2003), sees political violence as collective attacks within a political community against the political regime, its actors-including competing political groups, as well as incumbent or its policies. 


\section{Violence in Nigeria politics}

Contemporary events across the country have clearly demonstrated that Nigerian politics has been bedevilled with violence. Since the 60's, no regime can be said to be free from the 'syndrome' of political violence, both military, and even more in the civilian regimes, that have adopted the 'dastardly' practice (Gboyega in Kwanashie 2004, P.6). Violence has been regrettably elevated to a 'fashionable' status within many nations' polity, including Nigeria. Violence has become a determining factor in the political, especially electoral machinations and outcome. Political power seekers have institutionalized violence to the point of subverting the constitutions. The employers of violence - "godfathers, and their sons" thus have been placed over and above the laws of the land. They carry arms without hindrance, they have military, paramilitary, mobile Police, civil defence, escorts to abduct, kill, maim and harass their targets - contenders (Alubo, 2011).

Another way 'leaders' have institutionalized violence in politics is by employing 'illiterate' thugs as "special advisers, special assistants, contractors (for their loyalists), who cannot "special-advice or assist" in any meaningful and positive way. Some of the touts are commissioned as "party agents", chairmen of local governments, pooling officers, monitoring officers, who often overpower, intimidate, official personnel posted to do such assignments; causing violence and crisis in voting arenas to impose their figures, snatching boxes etc. (Adeyemi, in Ekweremadu, 2009). He expresses concern over the increasing state of violence in Nigeria, "in recent times there has been much concern about Nigeria's survival as a nation, since the return of democracy in 1999, there has been a drift from one violent conflict to another, often with devastating consequences on human life and socio-economic development".

\section{Socio-economic development}

Socio-economic development is any activity, or programme that creates sustainable access to the economy for its beneficiaries. This means that, contribution from stakeholders should provide sustainable benefits, to use the old saying; socio-economic development projects should teach (equip) people to fish, rather than given them fish (politicizing and impoverishing) them (NEPAD, 2003). Socio-economic development is the relationship between economic activity and social life. The NEPAD declaration implies that socio-economic development is the continuous improvement in the well being and in the standard of living of the people. It connotes meeting the basic needs that are essential to live a life of dignity by the people. This includes access to quality education, better health-care, decent housing, safe drinking water, and good sanitation of the nations' wealth.

Socio-economic development is measured with such indicators as life expectancy, literacy, functional education, employment, and GDP. The impacts of socio-economic development are seen in positive changes in law (rule of law) and the supremacy of the justice system, changes in physical environment - curtailing the forces of denudation that often render environment inhabitable, and changes in ecology. Socio-economic development also requires action that will strengthen policies, delivery mechanism of outputs in key social development areas - food, educations, Health care/HIVIAIDS, child welfare, gender equity (fair treatment) and the protection of the vulnerable groups - women, youths, children, the aged and the disable. There is the need to address poverty, by reducing the suffering of the less privileged and increase their access to social services/amenities, and to increase the poor people's ability to generate an income of their own, in order to liberate them from vicious circle of squalor, diseases and excruciating poverty.

Therefore, the key objectives of socio-economic development are:

1) Promote self reliance in developments, and build capacity, (skill acquisition training, loans,) for selfsustaining development.

2) Strengthen policies, delivery mechanisms

3) Ensuring affordable access to water, food, sanitation, finance, markets, ICT, shelter and land, especially for the rural poor. 
4) Progress towards gender equity (fair treatment and access by all gender to opportunities) in all critical areas of concern including education, employment, elective positions, appointments etc.

5) Encourage broad base participation in reaping of outputs and opportunities of development by all stake holders at all levels (NEPAD/HSGIC-03-2003/APRM/Guideline/OSC/9 march 2003).

\section{Causes of political violence}

Sederberg (1994) attribute violent behaviour to two theses - the "killer Ape Thesis" and the "Cherry pie Thesis". According to him, the killer Ape thesis states that, humans are biologically programmed to be inherently violent, ie, hereditary genes pass on violence from generation to generation; we have no choice in the matter of violence.

The Cherry pie Thesis on the other hand locates violence in our cultures. That it is our cultures that bread us into violent beings - the socialization we receive; the environment in which we live, the era in which we are born and reared, the economic status we hold. Cherry Pie explains the long standing war between England and Ireland only with respect to history - due to some past injustice, which must continue in the future.

Another reason for political violence is supplied by Mohoshin (2009), in his study of "Youth Development in Bangladesh", which tallies with the situation in Nigeria, is the issue of what he termed "blind support for party politics", replacing the glory of knowledge base debates, with incisive statements resulting to violent contest; especially now that hooliganism has replace constructive exchange on part of youths/students, and the contending parties on the other hand. At a point in history, Bangladesh, as was the case in Nigeria, student/youths, workers' communities (unions) were the educated section of the society that could fight for the rights of the people, playing leading roles. These days, students, workers, and whatever unions are used as wings of political parties. Civil societies are no longer agents of socio-economic and political development of their affected communities. Instead they perpetuate the agendas of politicians and godfathers.

Kayode O. (citing El-Rufai, 2012), attributes political violence in Nigeria to failure of governments at all levels in applying states' revenues on improving the welfare of citizens. Instead, the federal allocation funds, and the IGR combined are spent on running their governments (El Rufai - Nigerian village square, $25^{\text {th }}$ July, 2012). The federal, states and local, governments are not ploughing resources into investments that will enhance their productive capacities. Nor are they allocating funds to the development of both social and economic infrastructure, what we are experiencing in Nigeria, according to Kayode (citing El Rufai 2012), "is a massive obstruction of access to government and power by a narrow group of people (the can- go -cult of political class) who continue to take advantage of their past and present positions and network within and outside the bureaucracy to create an unofficial albeit, controls resources, power, and authority".

They work with government in power (dictatorship or democracy). Will do anything by any possible means to oppress and marginalize the civil society with a view to preventing them access to power, economic resources. This way they nurture corruption as a way of retaining continuous control; corruption has enjoyed great legitimacy, and completely undermined government/public socio-economic development structures and international image, entrenchment of massive poverty and reckless extortion, which has become a feature of Nigerian Federation today-in hospitals, schools, and high ways. These kinds of practices create resentment and cynicism, which burst into violence at the slightest provocation (Kayode, 2012).

Roger B (2009) identifies social problems as one of the causes of political violence. Social problems at different levels of group inequality and youth unemployment have increased the propensity for violence. The dominant discourses in the conflicts refer to political exclusion on the basis of ethnicity and religion. A key element of dispute is over which groups are represented in government, and have access to state, with much controversy over how state and local governments exercise power. For this reason, the conflicts need to be placed in the context of the local political economy (Kane, 2003, Marshall, 1995, in Roger, 2009). 
Raul (2004) identifies poor economic condition and lack of economic opportunities, to favour political violence. Poverty and income inequality would feed frustration; hatred and grievance make political violence more likely. Gur (survey, 2010) seems to be in agreement with Raul, when he explains political violence with his "economic discontent", also known as relative deprivation theory. According to him, the back bone of the theory is the "perceived discrepancy between expected 'pay off' and actual 'pay offs' of individuals. When these discrepancies become collective, they feed anger and frustration, which translate easily into violent behaviour.

Esew (2003) summaries the causes of political violence to include: Domination, and marginalization of sections, groups, and persons in the acquisition and sharing of political positions, rigging of elections, manipulation of political process in favour of certain groups, sections, persons; and falling apart of sponsors and sponsored over contracts, appointments or methods of management of the states.

\section{Impacts of political violence on socio-economic development}

Political violence deprives women of the opportunity to participate in a climate of thuggery, killing, maiming, because they carry an essence that is not violence compliance. Thereby robbing the society of the subtle, tenacious managerial capacity that only women can give (Olugbemi, 2003, Adeyemi, 2003, Ogeltope, 2003; in Kwanashie, 2003)

The syndrome of given appointment to unskilled, unqualified thugs, leaving the skilled people branded "Opposition" has caused unprecedented decay in governance, low productivity in the entire civil service and general apathy in the society (Alubo, 2009).

Business people suffer serious losses as a result of political violence. Others move their businesses elsewhere, which are a serious blow on the economy of the affected state, city, community. Causing congestion in places of destination.

There is politicization of social services, amenities, (electricity transformers, roads, farm-imputes) other people belonging to "opposition parties" are not to benefit from provision of such amenities.

The massive destruction of life and property, throwing family members into grief, and misery. There is erosion of confidence in the law enforcement agents, and general feeling of insecurity.

\section{The way forward}

There is dire need for a synergy between public and private sector for better coordination, supervision and proper channelling of society's resources and opportunities to the right places, persons, to assuage the suffering of the people. In doing this, the right information is very important, in order to alley the growing cynicism and resentment of the public, especially against government/functionaries that often burst into anger and violence. There is therefore need to create easy access to information about government activities through easy outlets to reach every segment of the society - not paid or hijacking of media units by government functionaries without concrete ends (Howell A. 2004).

There is need for total overhaul of the social, economic, political, cultural, religious policy statements, implementation and supervision to reflect the current reality in the country.

Time has come for government to take the civil service seriously - make it workable in their roles, regarding the enactment, implementation, funding, quality control, step-by-step supervision, application of sanctions to violations of rules and regulations.

The decay in the justice system in this country needs to be addressed. There is dire need to allow "separation of powers" and the 'independence' of the judiciary to bear; an independent funding be created for the judiciary and it should be removed from the direct control - appointment of and removal of judges massive renovation of courts all over the country to create a "new feeling" and establish 'new justice instinct'. 
Workers, students, civil society unions/organizations, and the intellectual community need to either track-back, or evolve unionism or activism of dignity, based on sound socio-political philosophy that is people oriented, with achievable goals and objectives. Campuses of tertiary institutions should be rid of partisan politics; stakeholders should take steps to make students/youths activism a process of leadership building capacity for future leaders; and this is an urgent step that must be taken (Mohoshin, 2009).

The judiciary should engage in the realistic interpretation and application of the constitution; the political elite should be stopped from subverting the constitution in order to minimize the cases and issues of "non indigenes" and 'settlers' thereby reducing 'Politico-religious' violence.

Finally, the security operatives should be educated on democratic ideals, as they often use barbaric and unlawful means of "instilling law and order", which many times rather entrench crimes and break down of order (Alubo, 2011).

\section{References}

Mohoshin, A. (2009). Youth Development in Bangladesh: Accessed at http://www.modernghana.com/news/223852/1/ youth-development-in-bangladesh.html

Kayode,O.(2012). Accessed at: http://www.nigeriavillagesquare.com/article/kayode/nigeria-diaspora-developt-by-kayode$\mathrm{html}$

Kayode O. (2004). Structural problems for socio-economic development in Nigeria at http://www.nigeriavillagesquare.com/nasir-el-ruffai/state-budget-wrong-priorities-pathetic-out-coms.html

Howell, A. (2004). Political Thuggery in Vogue. Chicago: L \& T press Ltd.

Agagu, A. and Ola, R. ed (2004). Development Agenda of the Nigerian State. Ibandan: Fiag publishers.

Guri, T. (1987), "Why Men Rebel". Princeton: Princeton university press

Karl, S. (1990). The politics of violence, Engle wood cliffs N. J. prentice Hall Inc.

Sederberg, P. C. (1994). Fires within: Political violence and Revolutionary change. Harper Collins - College press

Roger, B. (2009). Recent research on the Plateau languages of central Nigeria, available at http://www.rogerblench.info/language...

Roger, B. (2004). Natural Resources conflicts in North-central Nigeria: a hard book and case studies London: Manderas publishing

Enwerem, I. M. (1995). A dangerous awakening: The politicization of region in Nigeria. Ibandan: IFRA

Raul, C. Schneider, G. (2010). The Socio-economic determinism of Terrorism and political violence in Western Europe (1994-2007) accessed at SSRN http://ssrn.com/abstract=1693376

NEPAD/HSGIC - 03 - 2003/APRM/Guideline/OSC/9 March

Alubo, O. (2008). Ethnic conflicts and citizenship crises in central Nigeria. Ibandan: PEFS, Nigeria

Alubo. O. (2012) Sociology: A concise introduction. Jos: Ichejum press Nig. Ltd.

El Rufai - Nigeria Village square. 25th July, 2012 
